Editorial

\title{
Problems of Ethics and Scholarship in Nursing Publications
}

\author{
Lynn McDonald* \\ Department of Sociology and Anthropology, University of Guelph, Canada
}

\begin{abstract}
This article relates the flagrant instances of misinformation on Florence Nightingale, the major founder of professional nursing, in 2020, the bicentenary of her birth, and 2021. It notes the new trend to "pair" Nightingale with another supposed "nursing pioneer," who was a businesswoman and generous volunteer, Mary Seacole, but who never portrayed herself as a nurse. The article goes on to cite the promotion of misinformation on the two by no less than the Queen, in her Christmas message of 2020, and by her heir, the Prince of Wales, on 12 May 2021, Nightingale's birthday and International Nurses Day. The most extreme example of misinformation is that of the prince, who claimed joint status for Seacole with Nightingale in achieving the sanitary reforms in the Crimean War that saved large numbers of lives. Unlike Seacole, Nightingale played a role in these reforms, but credited the doctors and engineers of the Sanitary Commission who did the heavy work of renovation.
\end{abstract}

The article calls for high standards of ethics and scholarship in nursing and health care publication. Health authorities, such as Britain's National Health Service, should be the source of reliable information, especially in a pandemic. Misinformation on mere "historical" matters, not clinical, is not acceptable. Diversity and inclusion are valid goals of any health care system, but should be pursued with integrity. The article introduces a fine Black nursing leader, Kofoworola Abeni Pratt, who is ignored and yet should be celebrated for her contributions to nursing both in England and her home country, Nigeria.

Keywords: Florencenightingale, Nursing pioneers, Ethics, Scholarly standards, Misinformation

Abbreviations: NHS: National Health Service

\section{Introduction}

The bicentenary of Florence Nightingale, 2020, oddly became the occasion for the publication of articles denigrating her work, and even making extreme accusations of fault against her, without any documentation. Evidence against such attacks, using primary sources, has subsequently been published. ${ }^{1}$

These attacks have typically been linked with the promotion of Mary Seacole, said to be a pioneer nurse, although again without any evidence as to what she pioneered, and contrary to her own description of her contributions in her engaging memoir, Wonderful Adventures of Mrs Seacole in Many Lands, 1857. Then came the announcement by the Florence Nightingale Foundation that it was partnering with the Mary Seacole Trust in the awarding of Seacole Leadership Awards. Yet the purpose of the Foundation, proposed in 1912, two years after Nightingale's death, was to enable nurses to prepare themselves"to follow in her footsteps." The proposal came from Ethel Bedford Fenwick, a major British nursing leader, at a meeting of the International Council of Nurses, which immediately adopted it. Fenwick was commissioned to take charge. However, given the disruptions of the First World War, it was not until 1929 that the foundation came into operation. ${ }^{2}$

\section{The Rewriting of Nursing History}

The Florence Nightingale Foundation gave as its justification for the 2021 change in purpose the statement that Nightingale and Seacole were "active at the same time and are both considered pioneers of modern nursing." They were indeed "active" at the same time, Nightingale in running the nursing and bringing in needed supplies for the army hospitals of the Crimean War, Seacole in running a business (store, bar, restaurant and catering service) for Brit-
Quick Response Code:
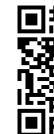

\footnotetext{
*Corresponding author: Lynn McDonald, University of Guelph, Guelph ON, N1G 2W1, Canada

Received: 19 May, 2021

Published: 31 May, 2021

Citation: Lynn McDonald. Problems of Ethics and Scholarship in Nursing Publications. Trends Nur Health Care Res. 2021;1(1):1-2. DOI: 10.53902/TNHCR.2021.01.000505
} 
ish officers in the Crimea. According to Seacole's account, they met once, briefly, when she asked Nightingale for a bed for the night at her hospital as she was leaving the next day for the Crimea. Nightingale found one for her. ${ }^{3}$ There is no mention of the incident in any of the thousands of letters and numerous reports Nightingale wrote. Yet the Foundation's CEO, Greta Westwood, transmogrified this friendly service into a "partnership" (!)so that joining them in the awards "reunited them" from the encounter 166 years earlier. ${ }^{4}$

Questions put to Westwood to as to what hospitals Seacole ever nursed in, any nurses she trained or mentored, and any books or articles she ever wrote on nursing went unanswered. The answer for each is nil: Seacole did not nurse one day in any hospital in any country of the world, and never said she did. Her one book, the travel memoir, gives menu details and recipes for her restaurant. She describes voluntary services she gave, but there is nothing remotely connected with founding a profession. A timeline is available that lists major activities of both Nightingale and Seacole, where it is evident that they do not coincide. ${ }^{5}$

Major British institutions have engaged in this rewriting. The BBC has put out much misinformation, while the National Portrait Gallery in Londonfor many months displayed a banner of Seacole wearing medals she did not earn, alongside a banner of Lord Nelson, winner of the Battle of Trafalgar, wearing medals he did earn. Six university buildings in the UK are named after Seacole, not a one after Nightingale. The Royal College of Nursing has a Mary Seacole Lecture, but not one to honour Nightingale, which the Royal Statistical Society has.

St Thomas' Hospital, home of the original Nightingale School, founded in 1860, now has a massive statue of Mary Seacole on its grounds, visible from the House of Parliament across the Thames River, compared with only a modest statue of Nightingale inside a building, seen by few. Yet it was Nightingale who wrote to and met with British members of Cabinet and members of Parliament to press for health care reforms, most notably the raising of the standards of care (bringing in professional nurses) to the dreaded workhouse infirmaries, the only "hospital" recourse then for those who could not pay hospital charges.

The National Health Service (NHS), the first single-payer system in the world, is inconceivable without the reforms that Nightingale worked for. At least 80 percent of "hospital" patients in her time were, in fact, in workhouses, which still had bed sharing, were overcrowded and badly ventilated, and had no trained nurses.

\section{Rewriting Health Care History}

An articlein the Times by the Prince of Wales takes the misinformation about the two "nursing pioneers" to a new level of misinformation, by crediting Seacole with Nightingale for the broader public health, "sanitary," reforms that saved lives, not a subject Seacole ever broached. Her memoir contains not one mention of the work of the Sanitary Commission that did the crucial clean-up of the unsanitary conditions of the war hospitals. Yet, says the prince, "It was their emphasis upon hygiene that was credited with saving so many lives. They pioneered the implementation of sanitary regulation in field hospitals so that the wounded could be looked after."

\section{Diversity and Inclusion on Nursing and Health Care}

Diversity and inclusion are now, rightly, goals of nursing and health care institutions. This laudable objective, however, has been made the excuse for the falsification of nursing and health care history more broadly. Pandemic or no pandemic, people should be able to trust the information provided by health authorities.

The promotion ofSeacole, valid as its objective is, has led to an obvious injustice: failure to recognize genuine Black and minority nursing leaders, Probably the best example of an unheralded Black nursing pioneer is Kofoworola Abeni Pratt (1915-92), the first Black nurse in Britain's National Health Service when it opened in 1948, who went on to being the first Black matron ofUniversity College Hospital, Ibadan, to being chief nurse in Nigeria and even on to becoming the first nurse to become a Cabinet minister responsible for health in her country (in Lagos State, 1973-75.) In that, she even passed Florence Nightingale (her model), for while Nightingale wrote to and met with Cabinet ministers on nursing and health care reforms, Pratt actually became the minister herself, with, naturally, a male medical doctor as her deputy minister.

\section{Conclusion}

Leaders in nursing and health care, and their publications, should adhere to high standards of scholarship and ethics in any material they bring out, and make corrections when errors are brought to their attention. Diversity and inclusion are valid goals, but must be pursued with integrity; propaganda and false facts do not become acceptable as per "the end-justifies-the-means," not at any time. NHS propaganda on matters only "historical," not clinical, is not acceptable.

\section{Acknowledgments}

None.

\section{Funding}

None.

\section{Conflicts of Interest}

There is no conflict of interest to declare.

\section{References}

1. McDonald L. Florence Nightingale: reflections on diversity, the National Health Service and the coronavirus pandemic. ECNH. 2021;3(3):26-31.

2. Ward U. The Florence Nightingale Foundation: developing nursing's leaders. BrJ Nurs. 12;27(13):774-775.

3. Seacole M. Wonderful adventures of Mrs Seacole in many lands. Oxford: Oxford University Press; 1988.

4. Mitchell G. Mary Seacole Awards to be taken over by a new partnership to "broaden impact." Nurs Times. 2021.

5. McDonald L. Mary Seacole: the making of the myth. Toronto: Iguana; 2014.

6. HRH Prince of Wales. Nurses have done so much to make the nation proud. The Times. 2021. 